\title{
Assessment of quality of life of amputee in war victims
}

\author{
Bashar J. AL-Jawary, Saad H. Murad \\ Nursing College, Mosul University
}

(Ann. Coll. Med. Mosul 2008; 34(1): 42-53).

Received: $18^{\text {th }}$ Jun 2007; Accepted: $23^{\text {rd }}$ Apr 2008.

\section{ABSTRACT}

Aims: To assess the quality of life (Q.O.L) of amputee patients and the relation with some variables.

Methodology: A descriptive study was carried out at Al-Mosul rehabilitation center during the period from $10^{\text {th }}$ April to $30^{\text {th }}$ June 2004. The sample of the study consisted of 160 amputee patients with lower limb amputation selected randomly. The data was collected by using assessment tool which consists of (66) items distributed to three domains (physical, psychological and social).

Results: The results of the study show that there are many problems in all areas through the amputee patient's life. The psychological problems come in the first rank among problems faced by amputee patients, while the physical and social aspects come later throughout the amputee patient life. Significant differences were found between the quality of life of amputee patient and variables of study (age, social status, level of education, urbanicity, level of amputation, reason of amputation and using assistance device).

Recommendations: The study recommended to establish rehabilitation centers to accommodate war victims; training program should be carried out in special workshop for vocational rehabilitation therapy and educational programs for families of amputee patients for care to provide and improve quality of their life.

$$
\begin{aligned}
& \text { الخلاصة }
\end{aligned}
$$

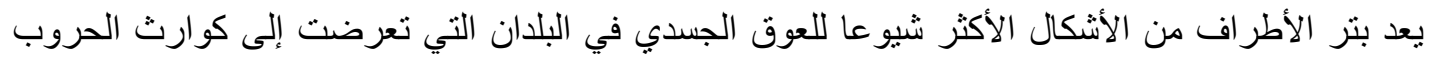

$$
\begin{aligned}
& \text { المتكررة وألازمات الداخلية والتي بدورها تسهم في زبادة عدد حالات العوق بسبب البتر بمختلف الأشكال }
\end{aligned}
$$

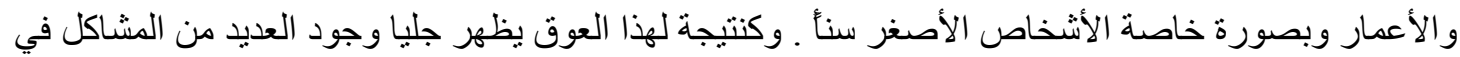

$$
\begin{aligned}
& \text { مختلف المجالات والأوجه، الجسدية، النفسية والاجتماعية والتي تؤثر على نوعية حياة مرضى البتر و وعوائلهم. } \\
& \text { الههف: تقييم نو عية الحياة لمرضى البتر و علاقتها ببعض الاضه المتغير ات. } \\
& \text { المنهجية: در اسة وصفية أجريت في مركز الموصل للتأهيل لتقييم نوعية الحياة لمرضى البتر خلال الفترة من ون }
\end{aligned}
$$

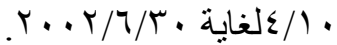

$$
\begin{aligned}
& \text { عينة الدر اسة تكونت من ( • } 1 \text { ( ) مريضأ لديه بتر في الطرف السفلي كير اجعون بصورة دورية مركز الموصل } \\
& \text { للتأهيل في مدينة الموصل. }
\end{aligned}
$$

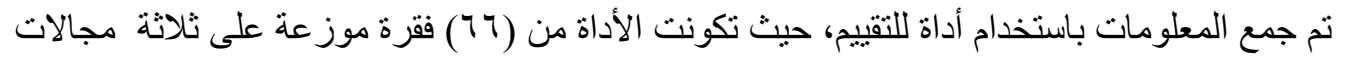

$$
\begin{aligned}
& \text { (المشكلات الجسدية ،المشكلات النفية ، المشكلات الاجتماعية). }
\end{aligned}
$$




$$
\begin{aligned}
& \text { تم تحديد مصداقية وثبات أداة الدراسة و نم التأكد منها عبر أجر اء دراسة تمهيدية أولا وثم عبر عرض أداة } \\
& \text { البحث على (7 (1 ) من الخبر اء في مختلف الاختصاصات. }
\end{aligned}
$$

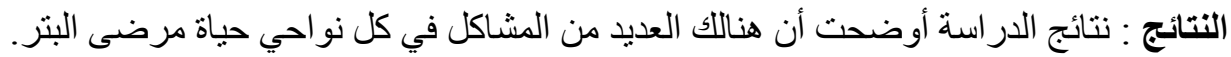

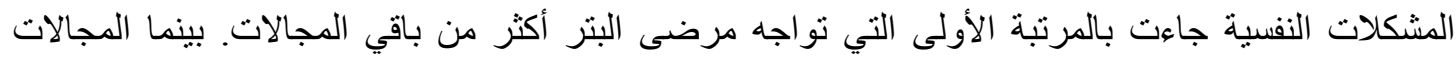

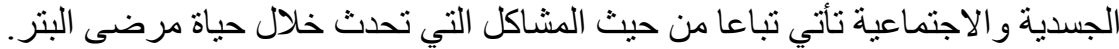

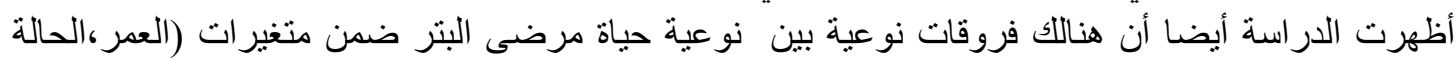

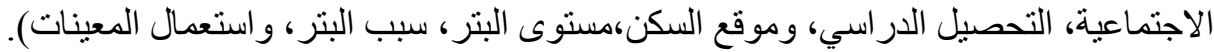

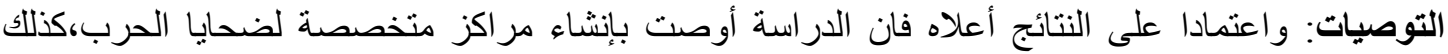

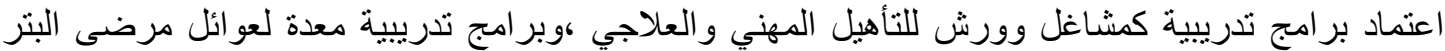

$$
\begin{aligned}
& \text { حول توفير الر عاية وتحسين نوعية حياتهر. }
\end{aligned}
$$

\section{A mputation can be considered as a type of reconstructive surgery that} is used to relieve symptoms, improve function, and save or improve the patient's quality of life ${ }^{(1)}$.

Approximately $90 \%$ of amputations involves the lower extremity; major advances have been made in both technique and prosthesis fitting for belowknee amputations. Most lower limb amputations in patients between 18 and 60 years of age are due to trauma or cancer. In those younger patients, not only training in physical mobility and independence in activities of daily living is important, but also, return to work or school which plays an important role. The functional level of both patient groups depends on the interaction between physical, mental, and social factors ${ }^{(2)}$.

Limb loss is a potentially devastating event in a person's life, however many patients have successful quality of life Q.o.L adjusted to their amputations, while others are found to be unable to do so; they have developed many disorders which have required strict consideration and special intervention ${ }^{(3)}$.
Many of war survival disabled amputee patients express a number of problems accompanied with their physical limitations. They experience an altered body image, lowered self-esteem, changes in their personal relationships and some of them bear social stigma associated with their disability (4)

The concept of Q.o.L is increasing in importance and growing as a valid indicator of whether a given medical treatment is beneficial. Q.o.L now represents a way to describe the overall results and treatment effort that make sense to individuals with amputation and health care professionals especially nurses ${ }^{(5)}$.

The concept of Q.o.L goes beyond the idea of activities of daily living, dose not necessarily encompass the social dimensions of Q.o.L, which include performance of social roles, mental acuity, emotional state, sense of well being and relationship with others ${ }^{(6)}$.

Conceptualization Q.o.L including assessing the problem of various domains of life (physical, psychological, social and spiritual) and importance of these domains both to life and to the individuals ${ }^{(7)}$. 
Q.o.L measures have a wide range of capabilities. These include psychological characteristics, social roles interactions, functional performance, intellectual functioning, perceptions, spiritual, and subjective health; its components describe standards of living function and general satisfaction of life ${ }^{(8)}$. Rehabilitation nursing has a role paramount to successful community reintegration. This can be implemented when clients are encouraged to maintain control over their environment by helping them to take responsibility for their physical, emotional, behavioral and health maintenance. For rehabilitation nursing these goals are extended to include achieving and maintaining an acceptable quality of life, ensuring that the clients' specific needs are addressed, and promoting adoption by clients and families to life change while optimizing wellness, collaboration with foundation, family's health care provider ${ }^{(9)}$.

Q.o.L Is influenced by how well nurse is able to help the patient in adjusting to the changes induced by amputation to achieve the highest possible level of performance and participation in life activities.

The study aims to (1) assess the Q.o.L of amputee patients according to the areas of complains (Physical problems, Social problems, and psychological problems); (2) study the relationship between several characteristics of the patients with amputation problems and the Q.O.L.

\section{Methods}

A descriptive study was carried out on out -patient clinic of Al-Mosul rehabilitation center, during the period from $10^{\text {th }}$ of April to $30^{\text {th }}$ June 2004 .

Tool of the study: in order to accomplish the assessment of the Q.o.L of amputee patients, a special tool was prepared by the investigators, which is based mainly on extended literature review, opinion of experts who deal with amputee patients, and conducting a preliminary study on a sample of 10 patients by asking them open-end questions. The assessment tool consists of three domains:

1- Physical problems 26 items.

2- psychological problems 25 items.

3-Social problems 15 items.

Each item had three options: Never $=1$, Some time $=2$, Always $=3$

The investigators submitted the tool to a panel consists of 16 experts in different fields of knowledge (rehabilitation, nursing, medicine, psychology, sociology, surgery, and statistics) to test its validity, all of them agreed on the final draft of the assessment tool.

A pilot study was conducted on a sample of 10 patients with amputation and the test was repeated on the same sample after a gap period of twenty days to test the reliability of the assessment tool; Pearson's coefficient correlation reveals significant correlation at $\mathrm{P}<0.01$.

Sample of the study consists of 160 amputee patients as victims of war with lower limb amputation, who attend periodically to the Mosul rehabilitation center according to regulation of center every 15 day for treatment and follow-up of patients. $70 \%$ were from younger age group , 55\% were single , about $75 \%$ were 
with low level of education and two - thirds of them living in urban area.

\section{Results}

Table 1 demonstrates a highly significant difference at $\mathrm{P}<0.001$ level between the Q.o.L of amputee patients in all domains (physical, Social, and Psychological problems) in comparison with the theoretical mean.

Table 2 demonstrates a significant difference in physical problems of amputee patients with variable (age, level of education, residence, reason of amputation, using assistance device).

Table 3 shows a highly significant differences at $\mathrm{P}<0.001$ level in the social problems of amputee patients with all variables of study except in social status of the patients.

Table 4 demonstrates a highly significant difference in psychological problems with all variable of the study except the age of the patients.

Table 1: Comparison between the means of the Q.o.L of amputee patients with the theoretical mean of the study tool by using t- test

\begin{tabular}{|c|c|c|c|c|c|c|}
\hline Domains & $\begin{array}{c}\text { No. of } \\
\text { patients }\end{array}$ & $\begin{array}{l}\text { Mean } \\
\text { Score }\end{array}$ & SD. & $\begin{array}{c}\text { Theoretical } \\
\text { Mean }\end{array}$ & t- value & Significance \\
\hline physical problems & 126 & 56.256 & 4.935 & 52 & 7.065 & 0.001 \\
\hline "Social problems & 118 & 32.563 & 3.644 & 30 & 8.895 & 0.001 \\
\hline $\begin{array}{c}\text { Psychological } \\
\text { problems }\end{array}$ & 129 & 53.063 & 5.277 & 50 & 7.341 & 0.001 \\
\hline
\end{tabular}

Table 2: Relationship between physical problems of amputee patients with the variables of the study.

\begin{tabular}{|l||c|c|c||}
\hline \multicolumn{1}{|c|}{ Variables } & No. of patients & B & Significance \\
\hline \hline Age & 128 & 2.700 & $<0.01$ \\
\hline Social status & 20 & 0.787 & NS \\
\hline Level of education & 133 & 3.494 & $<0.001$ \\
\hline Residence & 103 & 4.617 & $<0.01$ \\
\hline Level of amputation & 14 & -0.364 & NS \\
\hline Reason of amputation & 129 & 7.297 & $<0.001$ \\
\hline Using assistance device & 113 & 5.601 & $<0.001$ \\
\hline
\end{tabular}

B: problems of amputee 
Table 3: Relationship between social problems of amputee patients and the variables of the study.

\begin{tabular}{|l|c|c|c||}
\hline \multicolumn{1}{|c|}{ Variables } & No. of patients & B & Significance \\
\hline \hline Age & 128 & 1.313 & $<0.01$ \\
\hline Social status & 18 & 1.041 & $>0.05$ (NS) \\
\hline Level of education & 130 & 1.094 & $<0.001$ \\
\hline Residence & 128 & 3.057 & $<0.001$ \\
\hline Level of amputation & 124 & .907 & $<0.001$ \\
\hline Reason of amputation & 126 & 3.521 & $<0.001$ \\
\hline Using assistance device & 122 & 3.101 & $<0.001$ \\
\hline \hline
\end{tabular}

Table 4: Relationship between psychological problems of amputee patients with the variables of the study.

\begin{tabular}{|c|c|c|c||}
\hline Variables & $\begin{array}{c}\text { No. of } \\
\text { patients }\end{array}$ & B & Significance \\
\hline \hline Age & 32 & 0.306 & $>0.05$ NS \\
\hline Social status & 19 & 1.663 & $<0.05$ \\
\hline Level of education & 97 & 1.522 & $<0.01$ \\
\hline Residence & 121 & 5.618 & $<0.001$ \\
\hline Level of amputation & 108 & 1.858 & $<0.001$ \\
\hline Reason of amputation & 119 & 8.705 & $<0.001$ \\
\hline Using assistance device & 121 & 4.412 & $<$ \\
\hline
\end{tabular}

\section{Discussion}

In the few recent years there has been a rise in the number of disabled individuals especially those with physical disability, the occurrence is consequential due to consecutive wars which affect not only military members exposed to its disasters but also civilian people who are war victims too. Road traffic accidents and increase risk in the area of work are other factors which participate in the incidence of many persons with physical limitation as amputation of upper or lower extremities $^{(10)}$. 
Limb loss is one of the most serious events that a patient goes through, it doesn't affect the person physically only but also leads to different types of problems that are faced by the amputee patient himself. It makes patient disabled, dependent in many daily activities on the others, psychologically disturbed, and socially secluded, so most of the amputee patients, as result of this limitation, had many problems throughout their life ${ }^{(11)}$.

Rehabilitative Nurses have a vital role to play in observing, clarifying, assessing and recording all the problems that amputee patient faces. Also it gives the real needs of nowadays population by this special bias of information related to those individuals with these limitations to construct programs specialized in developing their new life adjustment ${ }^{(4)}$.

Table 1 shows highly significant differences in comparison between the Q.o.L of amputee patients in all areas of problems (physical, social and psychological) with theoretical means. The differences in physical problems may be due to deficit of practice to accommodate with these problems. It also may be due to dependency on other people in home living, or because of lack of information and practice due to lack of special nursing and medical team who are qualified to answer questions or due to short period which the patient is offered at rehabilitation unit. In distance walking the result is in agreement with the study of Muguwer (1998), which showed that 84\% used their prosthesis for more than 13 hours a day. In other study by Purry 1988 ,
$85 \%$ of them wear their prosthesis more than seven hours a day.

Walking distance seems to remain restricted in spite of the intensive training. $25 \%$ of persons with prosthetic limb can walk more than one kilometer and 19\% could walk more than 2 kilometers ${ }^{(14)}$.

The differences in psychological, and social problems in comparison between their means with theoretical mean is in agreements with the result of the study of Jacobsen (1998), which found that more than $86 \%$ of amputee individuals express types of frustration, psychological disorder, depression and family unacceptance.

The high level of amputation is in patient with above knee joint constituting 56,3\%. This result is in agreement with Isakov 1997, who stated that the most surgical operative amputation of lower extremity are done to young people at the level of above knee joint $70-80 \%$ of all cases which mainly resulted from accidental traumatic reason. On the other hand, this result is in disagreement with the result of Redondo 1997, who stated that most amputations were done at the transtibial level in cases of trauma or vascular damage. There is also a disagreement with results of Jones, 1994, who found in the earlier work by the National Center for Health Statistics NCHS in 1979, that 133.000 amputees in United states were performed in acute care nonfederal hospital, the majority were for lower extremity 105.000 , most of them 51.000 were toe or partial foot amputation, 24.000 were at the below knee level amputation, and 30.000 were at the above knee level. 
The majority of amputations in the lower limb were due to war; this result is with agreement with the study done in Vietnam by Miller 1988, which showed that lowerlimb amputations are much more common than amputations of the upper extremity; these wounds were caused predominantly by antipersonnel land mines and booby traps, $95 \%$ of the main causes were mining or direct missile attack.

\section{Age of amputee patients}

Age is one of the important variables that directly affect the amputee patient life. It is a well- known fact that the amputee patient age affects the other factors related to life, probably amputee patient is able to express or show more difficulties in his new life in certain domains than others. Aged amputee patients show difficulties in how they can treat or adjust to physical or health disaster ${ }^{(16)}$.

In addition, there are highly significant differences in psychological problems of amputee patients with regard to their ages. This result is in agreement with the study of Herbert (1999), who found that the ages of most amputee patients were between 23-42 yr. and have history of suicidal or psychological disorder such as depression or drug abuse.

\section{Social status of amputee patients}

Our results indicate that there are no significant differences between the quality of life with regard to social status of amputee patients. These results are in contract with Kohl, (2001) who stated that too many problems arise post traumatic procedure in most amputee person such as cases of divorce, hubby vamoose, and most people refuse to marry a disabled amputee person. Also it may be due to the effect of the new situation which makes the amputee patient sensitive to any type of help from other persons which is reflected on his life.

\section{Educational level of amputee patients.}

In order to know whether there is an effect of amputee patient's level of education on the quality of life, the researcher divided the sample to five groups according to patient's educational level. It appears from table 2,3 and 4 that there are highly significant differences in health problems of amputee patients with regard to the level of education. These results may be due to the differences in the knowledge of amputee patients and how they can manage with their physical problems. Howere there is no significant difference in the social problems of amputee patients with regard to the level of education.

\section{Use of Assistance device}

The majority of amputee patients in the study used elbow crutches, this is in agreement with the study of Krueger, (1994) who showed that most depending amputee individuals with above knee joint had abilities on the use of elbow crutches more than other assistant device. In the study of Sluttsky 1992, which was carried out on 109 patients, the result of research shows that $67 \%$ of them used the prosthesis limb more than others with the same level of amputation who used elbow or auxiliary crutches, $11.4 \%$ of all amputee patients. 


\section{Conclusions}

1. There are highly significant differences between the Q.O.L of amputee patient in all domains: physical, social and psychological with regard to the theoretical mean .

2. Highly significant differences were found between the Q.o.L of amputee patient with regard to the variables (age, level of education, residence, level of amputation, reason of amputation and using assistance device).

\section{Recommendations}

According to the results of the study, the investigators put forward the following recommendations:

1. Establish centers to accommodate war victims' amputee patients.

2. Establish special rehabilitation centers supplied by electronic modern devices and good training nurses to meet and identify the real needs of amputee patients.

3. Mass media has an important role to play in presenting the problems of disabled amputee patients, especially presenting educational programs to people through T.V. on the risk of minelayer.

4. Educational and training programs for families of disabled amputee patients to be able to provide the best possible care and to improve their quality of life.

\section{References}

1.Smeltzer S, Bare B. Textbook of medical surgical nursing. $9^{\text {th }}$ edition, Philadelphia, Lippincott, 2000, PP.1857-64.

2.Frank R, Kashani J, Kashani SR, Wonderlich SA, Umlauf RL, Ashkazi G S, psychological response to amputation as a function of age and time since amputation. British. Journal of Psychology. Vol. 144, No.35, 1994, PP.493-97

3.Caini DJ, Psychological considerations affecting rehabilitation after amputation, Medical Journal of Australia, Vol.2 No. 26, 1993, PP.818- 821

4.Pillitteri A, Psychiatric health nursing, $1^{\text {st }}$ edition, Philadelphia, Lippincott, 1999, PP. 192-98

5. Aronson PG, Assessing the quality of life of individual with handicap, European Journal of disability rehabilitation, Vol. 32,No.5, 1994,P.53

6.Levien IK, Quality of life in day activity, Journal of clinical medicine, (54), 78, 1997, P.24

7.Ferrans J, Quality of life in rehabilitation nursing, $2^{\text {nd }}$ edition, Neo York, Hall company, 2001, P.157

8. Witrrsok $E$, quality of life care plan for disabled patients. American journal of medical Rehabilitation, 127 (16), 1995, PP. 869-74

9.Shirley $\mathrm{PH}$, Rehabilitation nursing process and application, $2^{\text {nd }} \mathrm{Ed}$, Baltimore USA, Mosby- year Book, 1996, PP. 707

10.Dietthrich $\mathrm{k} \mathrm{J}$, Nursing management in orthopedic procedure, $1^{\text {st }}$ edition, New York, Saunders, 1996, PP. 21-23

11.Tower BO, satisfaction with care in disability patient, International Journal of Rehabilitation Research, 1992; 15:56,P.68

12.Muguwer SE, Critical psychiatric nursing care, $8^{\text {th }}$ edition, New York, Mc-Graw- Hill Book companies, 1998, PP. 65-68 
13.Purry J, Hannon, K, The hazards of immobility in disabled individual, American Journal of Nursing: 68, 23, 1988, PP. 758- 62

14.Sconnor SE, Nursing and rehabilitation: the interventions of nurses in amputee patient care. Journal of Clinical Nursing: 2, 1; 1993, PP.29-34

15.Jacobsen JM, Nursing role with amputee support groups. Journal of Vascular Nursing: 16, 2; 1998.PP.31-34

16.Kirkscey M, Mullins G, Psychosocial challenge of complexity in health care of amputee persons, Canadian Journal of Psychiatry, 37,28; 1992,PP. 92-98

17. Herbert L, Amputation in the vascular patient: Journal of Vascular Nursing: 76, 1; 1999,PP. 22-25

18.Kohl SJ, The Psychological Rehabilitation post amputation of limb, British Medical Journal: 32; (3), 2001,PP.62-68.

19.Krueger D, The processes of psychosocial adaptation traumatic limb loss, Journal of Medical Rehabilitation Society, 67(4), 1994,PP.654-657

20.Sluttsky C, Rehabilitation Management with movement disorder, Journal of Neuroscience Nursing, 23: 191,1992; PP.15-19.
21.Demarest CU, Using Prosthetic to aid independence in-patient with lower limb amputation, Patient self care, Journal of Nursing Education: 32, 265,15:1993, PP.94-96

22.Isakov E, Nursing intervention of persons after traumatic lower limb amputation, European Journal of Rehabilitation, 19:27,1997;PP.2-7

23. Jones $L E$, Epidemiological incidence of Lower extremity amputation in united state of America, American National Journal of Medicine, 91: 260,1994,PP. 2630 .

24.Miller $A D$, Variation in the incidence and proportion of disabled amputee person in Vietnam war, South Asia Journal for rehabilitation, 45:59; 1988,PP.42-48

25.Redondo $\mathrm{M} J$, Non traumatic lower extremity amputation in diabetic and non diabetic subject, Spanish Journal of diabetic metabolic disorder, 23: 519, 1997;PP. 52- 56. 


\begin{tabular}{|c|c|c|c|}
\hline دائما(س) & أحيلنا (r) & أبدا (1) & ألولا - المشكلات الجسية . \\
\hline & & & 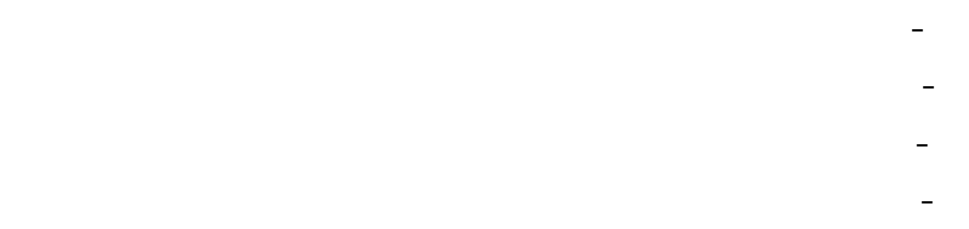 \\
\hline & & & 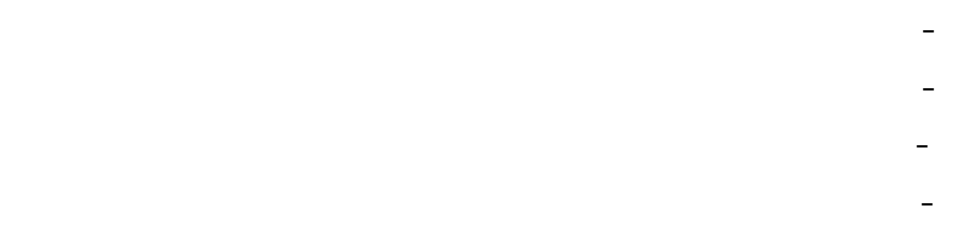 \\
\hline & & & 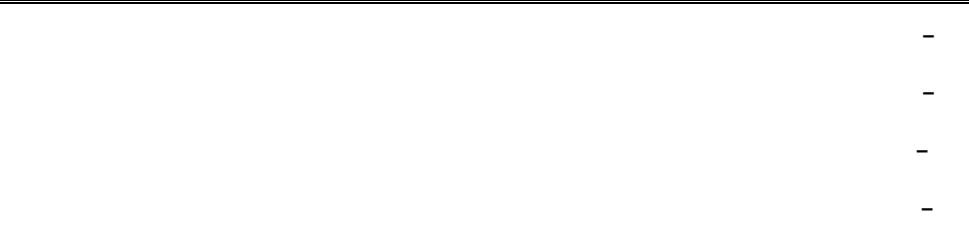 \\
\hline & & & 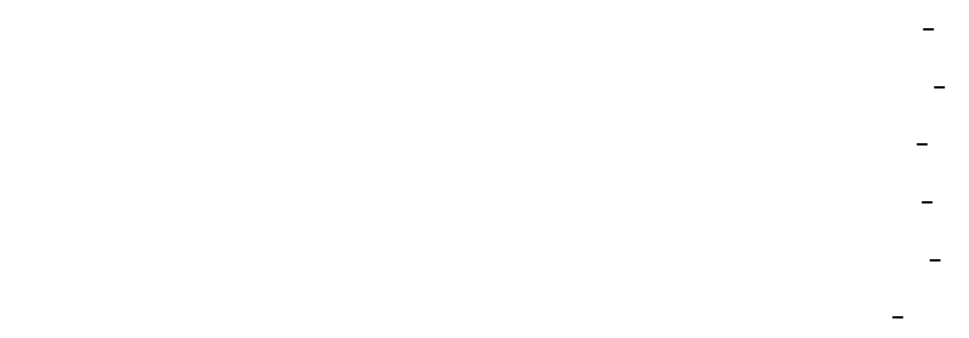 \\
\hline & & & 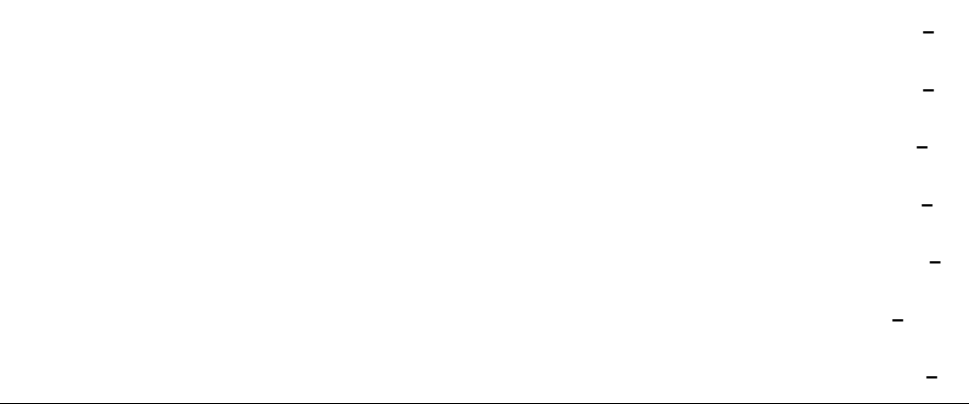 \\
\hline & & & 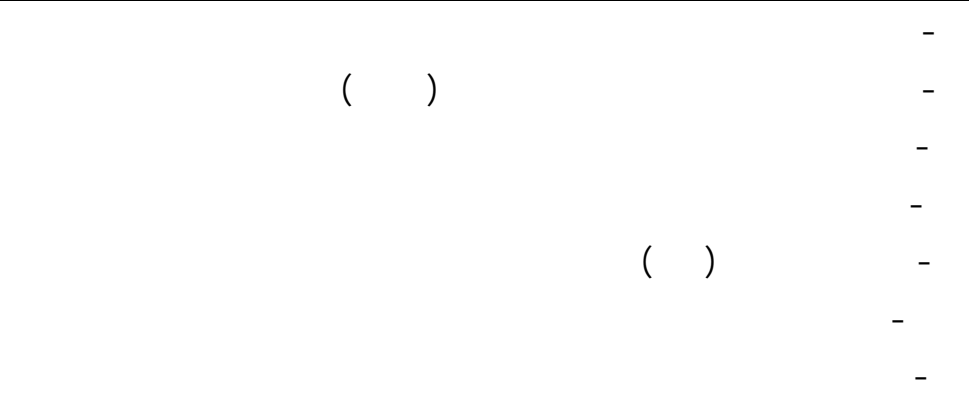 \\
\hline
\end{tabular}




\begin{tabular}{|c|c|c|c|}
\hline كأما (r) & ألحيلان(r) & 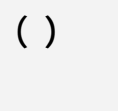 & 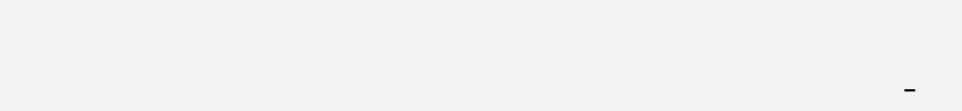 \\
\hline & & & 1 - أُشعر بان العوق هوسبب عطف الآخرين وشفقتهم علي - \\
\hline & & & r - أعاني من الإحبط والفثل بعد حصول العوق \\
\hline & & & "َ - أعالي من التوتر الافعالي بعد حصول البتر - \\
\hline & & & ع - ألشعر بالمرارة والألم نتيجة فقدان لُحد الطارف . \\
\hline & & & 0 - لُشعر بالحزن والكتئلب بعد الاصابة . \\
\hline & & & 7 - أعافي من عدم تفه الأسرة لحالتي الفسية \\
\hline & & & V أُشعر بالغيرة والققد عنما أظظر للآخرين وهم يتمتعون بسلامة الجسد · \\
\hline & & & 1 - فقدت الألم في المشي بعد حصول البتر · \\
\hline & & & 9 - أشعر بالغضب والانزعاج والمستنارة كلما تحدث الآخرين عن عققي . \\
\hline & & & · 1 - لـثشعر بعدم القدرة على مولجهة المشكلات اليومية · \\
\hline & & & 11 - ل لا لجد من يشجعفي من الأسرة على تجاوز الأزمة الني أعيشها . \\
\hline & & & كا - أُشُعر بانيشخص غير ذي فائة في الحيلة · \\
\hline & & & "ا - لمشعر بالانزعاج عند مرلجعة مرلكز رعاية المعقوقن · \\
\hline & & & عا - أثرت الإصابة بصورةسلبية على لحترلمي وقديري لذاتي (غقدان القة بالفس) . \\
\hline & & & 10 - ألشُعر بالانزعاج عند الظار إلى جسهي في المرأَ · \\
\hline & & & 17 - لم اعد قادرا على القيلم بولجبي في العطل كما كنتساقجا - \\
\hline & & & IV - غتدت اهتملمي وطموحاتي في الحيلة · \\
\hline & & & 1 1 - غقدت عملي الحالي وليس لي ألم في الحصول على عمل جديد \\
\hline & & & 19 - لمشعر أن أصدقائي يعمدون إلى تجنب التعلل معي · \\
\hline & & & r r - أنزعج عندما يظر النلس ألي . \\
\hline & & & اب - أتمف لوفقدت حياتي على أن أعبش معاقا جسيا \\
\hline & & & r r - أعالي من قلة النوم منذ حصول الإصابة . \\
\hline & & & بَّ - لمثعر بعدم وجود القدرة على لتخاذ القرارات إزاء المواضبع المختلفة \\
\hline & & & 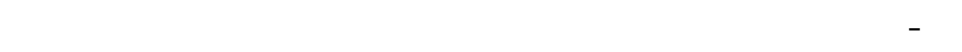 \\
\hline & & & r r - أفضل عهم الاختلطا بالناس \\
\hline
\end{tabular}




\begin{tabular}{|c|c|c|c|}
\hline (r) (rائما (1) & أحيلنا(r) & ألبا (1) & نالثا - المشكلات الاجتماعية - \\
\hline & & & I - لم اعد قادرا على ممارسة الأنثطة الرياضية \\
\hline & & & r - يعقد أفراد لمسرتي أنيشخص علجز · \\
\hline & & & بـ - يسخر الآخرون من إمكانياتي بعد حصول العوق \\
\hline & & & ع - أعاني من عدم وجود تسهيلات في مرلكز رعاية المعوقن . \\
\hline & & & 0 - لٔهس بعدم تعاون الكادر التمريضي في مرلكز الرعاية \\
\hline & & & 7 - أعاني من عهم توفر الدعم المادي من قبل الدولة \\
\hline & & & V - لم اعد قادر على المشاركة في المنلسبت الاجتماعية - \\
\hline & & & 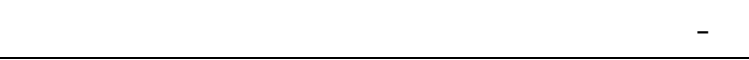 \\
\hline & & & 9 - تنف مستوى نخلي المادي بعد حصول الإصابة \\
\hline & & & ـ ا - لمشعر باني أششكل عالة على أهلي وأقاربي . \\
\hline & & & 11 | - ترلجع دوري في الأسرة وبصورةسلبية · \\
\hline & & & rا - تتنت معلملة ( زملائي ) معي بعد الإصابة - \\
\hline & & & سر - لم اعد قادرا على أداء دوري كزوج · \\
\hline & & & عا - الفدان لحد الأطراف أثركبير في أداء الصلة \\
\hline & & & 10 - لا أتمكن من الذهلب إلى مرلكز العبادة للأداء الصلاة \\
\hline
\end{tabular}

